Año L. urtea

$126-2018$

Uztaila-abendua Julio-diciembre

Sor 20

sats

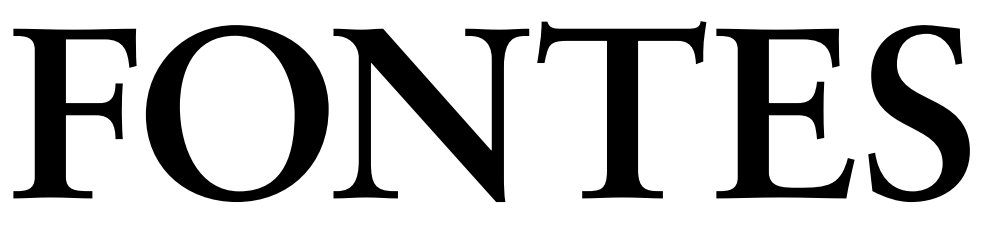

LINGVÆ

VASCONVM

STVDIA ET DOCVMENTA

SEPARATA

\title{
Inkoatibo/arazle alternantzia euskaraz eratortzen
}

Ane Berro, Beñat Oihartzabal, Beatriz Fernández

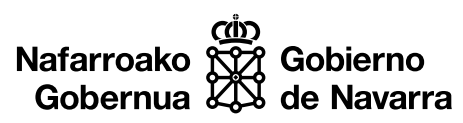

- 00 


\title{
Inkoatibo/arazle alternantzia euskaraz eratortzen
}

\author{
Derivando la alternancia causativa en euskera
}

Deriving the inchoative/causative alternation in Basque

\author{
Ane BERro \\ Deustuko Unibertsitatea \\ ane.berro@deusto.es \\ Beñat OiHARTZABAL \\ IKER UMR 5478-CNRS \\ b.oyharcabal@iker.cnrs.fr \\ Beatriz FERNÁNDEZ \\ Euskal Herriko Unibertsitatea (UPV/EHU) \\ beatriz.fernandezf@ehu.eus
}

\begin{abstract}
Eskerrak eman nahi dizkiegu $F L V$ aldizkariko bi zuzentzaile izengaberi lan honen lehen idatzaldiaz egindako zuzenketa eta iruzkinengatik, baita Fernando Zuñigari ere gogoeta tipologikoagatik. Lan honek Eusko Jaurlaritzaren diru-laguntza jaso du IT665-13 ikerketa proiektuaren bidez eta Espainiako Ekonomia eta Lehiakortasun Ministerioarena FFI2014-51878-P ikerketa proiektuaren bidez. Emaitza hauetara ekarri gaituen ikerketak Europar Batasunaren ikerketarako, teknologia garatu eta erakusteko Zazpigarren Esparru Programaren laguntza jaso du 613465 hitzarmenaren bitartez.
\end{abstract}

Jasotze data: 02/02/2018. Behin-behineko onartze data: 03/07/2018. Behin betiko onartze data: 17/07/2018. 


\section{LABURPENA}

Lan honetan, euskarazko aditzen inkoatibo/arazle alternantzia arakatu dugu. Proposatzen dugun analisian, inkoatibo/arazle alternantzia Boza alternantzia da: Bozak espezifikatzaile bat islatzen duenean, aldaera arazlea sortzen da; bestalde, Bozak argumenturik ez duenean espezifikatzaile gunean, aldaera inkoatiboa dugu. Wood-i (2016) jarraituz, alternantzian aurkitzen diren hutsuneak erroen interfaze-jarraibideei egotzi dizkiegu, eta batzuek dituzten esanahi idiosinkrasikoak erro-alosemiaren bidez azaldu ditugu. Azkenik, ergatibo subjektuaren rola eta arazle esanahia sintaxi konfiguraziotik eratortzen direla proposatu dugu, eta ez buru sintaktiko jakin baten islapenetik.

Gako hitzak: inkoatibo/arazle alternantzia; antikausatiboa; arazlea; egoera-aldaketa aditzak; Boza; aditz laguntzailearen txandakatzea.

\section{RESUMEN}

En este trabajo analizamos la alternancia causativa en euskera y proponemos un análisis de la misma como alternancia de Voz: cuando el núcleo Voz proyecta un especificador, se crea la configuración causativa; por el contrario, si el especificador no se proyecta, entonces surge la configuración incoativa. Siguiendo a Wood (2016), proponemos que la ausencia de una u otra de las configuraciones se debe a las instrucciones de interfaz de las raíces, y explicamos algunas acepciones idiosincrásicas apelando a la alosemia de las raíces. Por último, defendemos que el rol del sujeto ergativo y su significado causativo se derivan de la configuración sintáctica, y no de un núcleo sintáctico en concreto.

Palabras clave: alternancia causativa; anticausativos; incoativos; causativos; verbos de cambio de estado; Voz; alternancia de auxiliar.

\section{ABSTRACT}

In this work, we explore the inchoative/causative alternation found in Basque verbs. We propose that this alternation is a Voice alternation: when Voice has an argument in its specifier position, the causative variant emerges; in contrast, when there is no such argument, we get the inchoative variant. Following Wood (2016), we argue that the lack of alternation found in some verbs is due to the lack of a corresponding interpretation in the LF-instructions of those verbs. On the other hand, we explain the idiosyncratic meaning found in certain structures by means of root-allosemy. Finally, we propose that the interpreation of the ergative argument and the causative semantics is derived from the syntactic configuration, rather than from the projection of a certain syntactic head.

Keywords: inchoative/causative alternation; anticausative; causative; change-of-state verbs; Voice; auxiliary alternation. 
1. ATARIKOAK. 2. ArAZle LEXIKOAK ETA INKOATIBO/ARAZlE ALTERNANTZIA. 2.1. Egoera-aldaketa aditzak. 2.2. Posizio-aldaketa aditzak. 2.3. Leku-aldaketa aditzak. 3. EUSKARA UNIBERTSO TIPOLOGIKOAN: ADITZ LAGUNTZAILEAREN TXANDAKATZEA. 4. INKOATIBO/ARAZLE ALTERNANTZIA: AZTERBIDE BAT. 4.1. Inkoatibo/arazle alternantzia, Boz alternantzia gisa. 4.2. Inkoatibo/arazle alternantziarik gabeko errorik ba ote? 4.3. Erroen interfaze-jarraibideak. 4.3.1. Aldaera inkoatiboa edota arazlea onartzen ez dutenak. 4.3.2. Esanahi idiosinkrasikoko aldaerak eta erro-alosemia. 4.4. Ergatiboaren interpretazioa. 5. ONDORIOAK. 6. ERREFERENTZIAK.

\section{ATARIKOAK}

Jon Ortiz de Urbina irakasle miretsi eta adiskide maiteak jorratu dituen askotariko gaien artean daude egitura arazleak, Parameters in the grammar of Basque (1989) liburu gogoangarrian ez ezik, geroagoko lanetan ere aztertu dituenak (Deustuko Hizkuntzalaritza Mintegia, 1989; Ortiz de Urbina, 2003, agertzear). Guk lan honetan, inkoatibolarazle alternantzian agertzen diren arazle lexikoak (Comrie, 1989) aztertu nahi ditugu, zehazki egoera-, posizio- eta leku-aldaketa aditzekin batera jasotzen direnak, hala nola, egoera-aldaketa adierazten duten $h i l d a \mathrm{v} d u$ bezalakoak (Ortiz de Urbina, 2003, 592. orr.).

Alternantzia horiek eta bestelako arazle lexikoak, xehetasunez arakatu ditu Oihartzabalek (2003), eta Berrok (2015), arazle lexiko hauetan parte hartzen duten egoera-, posizio- eta leku-aldaketa aditzak dekonposatu ditu, erroaren kategoria aditza ez ezik, bestelakoa ere badenean. Adibidez, egoera-aldaketa aditzen artean agertzen dira: izenak (damutu < damu), adjektiboak (arindu< arin) edo postposizioak (ureztatu $<$ urez); eta leku-aldaketa aditzen artean, berriz, postposizioak (atera $<$ ate-ra) eta $-k a$ bezalako atzizkiak (mailakatu < maila-ka).

Euskara, bestalde, alternantzia ekipolenteak erakusten dituen hizkuntza da: erro bera ( $h i l)$ darabilgu aldaera batean zein bestean ( $h i l d a \mathrm{v} h i l d u$ ), eta aditz laguntzailearen txandakatzea da (izan $\mathrm{v}$ *edun) bata bestetik bereizten dituena (Haspelmath, 1993; Nichols, Peterson \& Barnes, 2004). Euskaraz ez dago, beraz, inkoatibo/arazle alternantzia adierazteko ez morfema arazlerik ezta antikausatiborik ere. 
Euskararen hautu tipologikoa gorabehera, lan honetan, euskararen inkoatibo/arazle alternantziari azterbide berri bat eman nahi diogu, Oihartzabalen (2003) azterbidea aintzat hartuz, baina aldi berean, zenbait alderditan bereiziz, Arazle burua errefusatuz besteak beste. Honi dagokionez, gure azterbidea Ormazabalena (2008) ez bezalakoa ere izango da. Lanean proposatuko dugunez, inkoatibo/arazle alternantzia Boz alternantzia da (Alexiadou, 2010, 2014; Alexiadou, Anagnostopoulou \& Schäfer, 2006, 2015; Wood, 2015, 2016 beste batzuen artean). Boz buru horrek, baldintza jakinetan, kanpo argumentua gaineratuko du bere espezifikatzailean. Ondorioz, aldaera arazlea eratorriko da. Kanpo argumentua gaineratu ezean, aldiz, aldaera inkoatiboa eskuratuko da. Arazle burua ez da, beraz, kanpo argumentua, hots, arazlea eratorpenera sartzen duen burua. Bestalde, aldeak alde, gure azterbideak badu Ormazabalen (2008) analisiaren antzekotasun zantzurik. Egile honen ustez, aldaera arazleak ez ezik, inkoatiboak ere badu kausa geruza bat, eta gure analisian, Arazle bururik ez dagoen arren, Boz buru bera dago aldaera batean zein bestean. Gainera, Ormazabalek (2008) bezala, bi aldaeretan gertakari egitura bera dela proposatuko dugu. Azkenik, erro batzuek testuinguru jakinetan jasotzen dituzten esanahi idiosinkrasikoak erro-alosemiaz (Wood, 2016) azalduko ditugu.

Lanak ondoko atalak izango ditu. Bigarren atalean, inkoatibo/arazle alternantzian parte hartzen duten aditzak aztertuko ditugu: egoera-aldaketa aditzak (2.1), posizioaldaketa aditzak (2.2) eta leku-aldaketa aditzak (2.3). Hirugarren atalean, inkoatibo/ arazlea adierazteko munduko hizkuntzen artean agertzen diren estrategia tipologikoen berri emango dugu eta euskara unibertso horretan non kokatzen den ikusiko dugu. Laugarren atalaren hasieran (4.1), inkoatibo/arazle alternantzia Boz alternantzia dela erakutsiko dugu; (4.2) atalean, alternantzia murriztapenak dituzten erroez eztabaidatuko dugu; ondoren (4.3), erro-alosemia arakatuko dugu eta azkenik (4.4), ergatibo argumentua arazle gisa nola interpretatzen den ikusiko dugu. Bosgarren eta azken atalean, ondorio nagusiak bildu eta gerora begirakoak zehaztuko ditugu.

\section{ARAZLE LEXIKOAK ETA INKOATIBO/ARAZLE ALTERNANTZIA}

Arazleen artean, badira bereziki egoera-aldaketa aditzekin zerikusia duten arazle lexikoak. Aditz horiek inkoatibolarazle alternantzian parte hartzen dute, ondoko adibide hauetan ikus daitekeenez.

(1) a. Katua hil da ${ }^{1}$

b. Haurrak katua hil du (Oihartzabal, 2003, 224. orr.)

1 Lan honetan ondoko laburdura hauek erabiliko ditugu: $\mathrm{a}=$ aditz txikia; $\mathrm{adb}=$ adberbioa; adj = adjektiboa; Boza = Boza; Boza $_{n}=$ Determinatzaile-tasunik ez duen Boza; Boza $_{\{\mathrm{D} \mid}$ Determinatzaile-tasuna duen Boza; $\mathrm{D}=$ determinatzailea; Denb = Denbora; e = event (ebentua); PTx = perpaus txikia; $\mathrm{s}=$ state (egoera). 
Adibide hauetan, hil egoera-aldaketa adierazten duen aditzak bi aldaera erakusten ditu: alde batetik, aldaera inkoatiboa (1a), zeinetan argumentu bakarra dagoen, subjektua alegia, eta gaia rol tematikoa eman zaion; beste alde batetik, aldaera arazlea, zeinetan gai osagarriari subjektu arazlea gaineratzen zaion. Egitura inkoatiboa iragangaitza da eta, euskara aditz laguntzailea txandakatzen duen hizkuntza den aldetik, izan da hautatu den aditz laguntzailea; aldiz, egitura arazlea iragankorra da eta hortaz, aditz laguntzaile iragankorraren erroa $-u$ - erakusten du -geroago ikusiko dugunez ( 2 atala), estrategia tipologikoen artean dago inkoatibo/arazlea alternantzia aditz laguntzailea txandakatuz adieraztea-. Azkenik, absolutiboa ezarri zaio argumentu bakarrari egitura inkoatiboan, eta ergatiboa eta absolutiboa ezarri zaizkie subjektu eta osagarriari, hurrenez hurren, egitura arazlean (ikus baita Etxepare, 2003, 391-2. orr. eta Ortiz de Urbina, 2003, 592. orr.).

Alternantzia honetan ager daitezkeen aditzak dira absolutibo argumentuak nolabaiteko aldaketa jasaten duela adierazten dutenak, hots, egoera-aldaketa aditzak (2), (1) adibideetan ere ikusi ditugunak bezalakoak, posizio-aldaketa aditzak (3) eta leku-aldaketa aditzak (4).
(2) a. Zuloa handitu da
b. Jonek zuloa handitu du
(3) a. Umea eseri da
b. Aitak umea eseri du
(4) a. Umea oheratu da
b. Aitak umea oheratu du

Bestalde, aditz bihurkariak (5), agerpen aditzak (6) eta jarduera/ekintza aditzak (7) ezin daitezke alternantzia honetan agertu. Argumentu bakarreko aditzak dira eta absolutibo subjektua dute, (2a) (3a) eta (4a) aldaerak bezalaxe, baina ez dira bateragarriak ergatibo subjektu arazle batekin (5b) (6b) (7b) (Oihartzabal, 2003).

$\begin{array}{llll}\text { (5) } & \text { a. } & \text { Pello orraztu da } & \\ & \text { b. } & \text { \#Maddik Pello orraztu du² } & \text { (Oihartzabal, 2003, 234. orr.) } \\ \text { (6) } & \text { a. } & \text { Nire oroitzen ondotik, bi mirakulu gertatu dira } & \\ & \text { b. } & \text { *Nire oroitzek bi mirakulu gertatu dituzte } & \text { (Oihartzabal, 2003, 237. orr.) } \\ \text { (7) } & \text { a. } & \text { Pello kanpoan jostatu da } & \\ & \text { b. } & \text { *Maddik Pello kanpoan jostatu du } & \text { (Oihartzabal, 2003, 235. orr.) }\end{array}$

Hurrengo ataletan (2.1-2.3), inkoatibo/arazle alternantzia onartzen duten aditz taldeak aztertuko ditugu xehetasunez, Oihartzabalek (2003) eta Berrok (2015b) egindako deskribapenetan oinarrituz -ikus baita Ormazabal (2008, 645. orr.)-.

2 Aditz bihurkarietan, aldaera iragankorra (5b) gramatikala da izatez, baina bere esanahia ez da (5a)ren gainean eraikitzen. (5a) adibidean, Pellok orrazten du bere burua, eta (5b)n, aldiz, Maddik orrazten du Pello. 


\subsection{Egoera-aldaketa aditzak}

Egoera-aldaketa aditzek barne argumentuaren egoeran -fisikoan zein psikologikoannolabaiteko aldaketa gertatu dela adierazten dute. Oihartzabalek aipatzen dituen aditzen artean ondokoak daude: arraildu, belztu, berotu, edertu, eritu, hautsi, hil, hoztu, idortu, puskatu, urtu eta zabaldu (Oihartzabal, 2003, 237-238. orr.). Gehienetan, aditzon erroa izen edo adjektibo gisa ere erabiltzen da aditzezko testuinguru horretatik kanpo (e. g. hotz, ur, zabal). Horregatik, hain zuzen, aditz horiek eratorriak direla proposatu izan da, hau da, aditz bihurtu baino lehen, izen edo adjektibo gisa islatu direla (Hale \& Keyser, 1993). Oihartzabalek (2003) ere ildo horri jarraitu zion, baina gure oraingo azterbidea bestelakoa izango da, geroago ikusiko dugunez (3. atala).

Beheko zerrendan ikus daitezke izen eta adjektibo gisa ere erabil daitezkeen erroekin euskaraz ditugun hainbat aditz. Izenezko aditzen artean, bi sail bereiz daitezke erroaren arabera (Berro, 2015b): (i) gizabanakoen ezaugarriak izendatzen dituztenak, eta (ii) egoera psikologiko zein fisiologikoak izendatzen dituztenak.

(8) Izenezko aditzak:

a. Gizabanakoen ezaugarriak izendatzen dituzten erroekin: adiskidetu, alargundu, amatu, apaiztu, atxilotu, gizondu, mutildu etab.

b. Egoera psikologikoak/fisiologikoak izendatzen dituzten erroekin: arduratu, aspertu, atsekabetu, beldurtu, damutu, egarritu, gosetu, haserretu, ilundu, izutu, zikindu etab.

(9) Adjektibozko aditzak:

a. Bakunak: aberastu, agortu, ahuldu, alaitu, argitu, arindu, apaindu, apaldu, argaldu, astundu, atzarri, azkartu, eskatu, garbitu, gorritu, moteldu, zuritu etab.

b. Konplexuak: ahaldundu, areagotu, betikotu, etxegabetu, etxekotu, euskaldundu, gaurkotu, gutxiagotu, itxuragabetu, larriagotu, zordundu, lotsagabetu, etab.

Adjektibozko aditzen artean ere, batzuk are gehiago dekonposa daitezke, alegia, adjektibo gisa erabiltzen dena ez da erro soil bat, baizik eta atzizki batez (-dun, -ago, -ko, -gabe) sortutako osagaia ${ }^{3}$.

Egoera-aldaketa aditzetan, arazle lexikoak erabat produktiboak dira (Oihartzabal, 2003), are gehiago, erroa izen edo adjektibo gisa erabiltzen denean testuinguru horretatik kanpo.

(10) a. Udaberriarekin bazterrak laster berdatu ziren

b. Udaberriak bazterrak laster berdatu zituen (Oihartzabal, 2003, 238. orr.)

3 -Ko eta -gabe postposiziotzat har litezke, eta ondorioz, beren gainean eraikitako aditzak postposizioetatik eratorritakoak direla pentsa liteke. 
Inkoatibo/arazle alternantzia murriztuagoa dute, aldiz, instrumentalaren gainean (eta harekin batera -ta- morfema gaineratuz) eraikitzen diren aditzek. Sail honetakoak dira, esaterako, ondorioztatu, legeztatu, argiztatu, balioztatu eta ureztatu. Talde honetan sailkatzen diren aditz gehienek aldaera arazlea onartzen dute bakarrik, eta ez inkoatiboa:

(11) a. Lorezainak geranioak ureztatu ditu

b. *Geranioak ureztatu dira

Alabaina, postposizio instrumentala daramaten aditz gutxi batzuek alternantzia onartzen dute (eg. odoleztatu, aireztatu, koloreztatu, gorriztatu).

(12) a. Aitak gela aireztatu du

b. Gela aireztatu da

\subsection{Posizio-aldaketa aditzak}

Inkoatibo/arazle alternantzia jasan dezakeen beste aditz talde bat posizio-aldaketa aditzena da. Predikatu horietan, barne argumentuak aditzak adierazten duen espazio konfigurazioa hartzen du eta horrela, barne argumentuak nolabaiteko aldaketa jasaten duela ulertzen da (Levin, 1993), 2.1 atalean deskribatutako egoera-aldaketa aditzetan bezalaxe. Sail honetan zerrendatu ditzakegun aditz batzuk hauexek dira: etzan, jaiki, eseri/jesarri/jarri, altxatu, kokatu, geratu, paratu. Bestetik, aditzezko testuingurutik kanpo erabil daitezkeen erroak dira: belaunikatu (<belauniko), gelditu (<geldi), zutitu $(<z u t i k$ ), zintzilikatu (<zintzilik) eta -ka atzizkiaz sortutako batzuk (mailakatu, lerroka$t u$, sailkatu). Erro edo osagai horiek adberbio gisa ere erabiltzen dira.

\subsection{Leku-aldaketa aditzak}

Leku-aldaketa aditzak dira, egoera-aldaketa aditzekin batera, inkoatibo/arazle alternantzia onartzen duten aditz-talderik handiena. Predikatu hauetan, barne argumentuak leku-aldaketa bat jasaten du eta aditzak mugimenduaren norakotasuna edo helmuga adierazten du. Bestelako mugimendu aditzek, hala nola, mugimenduaren modua adierazten dutenek, ez dute oro har horrelako alternantziarik erakusten.

Hemen zerrendatu daitezke aditzezko testuinguruan bakarrik erabiltzen diren predikatu batzuk (atera, joan, aldendu, amildu, arrimatu, goititu, igan/igo, jalgi, sor$t u$ ). Nolanahi ere, talde honetako aditz gehienen erroek edo barne osagaiek bestelako erabilerak dauzkate aditzezko testuingurutik kanpo: batzuek adberbio gisa (hurbildu $(<$ hurbil), urrundu (<urrun)) eta gehienek adlatibo postposizio sintagma gisa (Berro, 2015ab). Azken horietako batzuk zerrendatu ditugu behean.

aberriratu, adineratu, argitaratu, aurreratu, aitzinatu, alboratu, alderatu, atzeratu, atzerriratu, aurpegiratu, azaleratu, azpiratu, barneratu, barruratu, basoratu, bateratu, begietaratu, bururatu, elkarretaratu, elizaratu, etxeratu, itsasoratu, lehorreratu, mahaigaineratu, etab. 
Postposizio instrumentalaren gainean eraikitzen diren aditzek ez bezala, adlatibo postposizioaren gainean sortzen diren aditzak guztiz emankorrak dira eta oro har, inkoatibo/arazle alternantzia izaten dute (Oihartzabal, 2003).

(14) a. Umea oheratu da

b. Aitak umea oheratu du

Adibideotan ikus daitekeenez, oheratu aditzak argumentu bakarra (14a) edo bi (14b) har ditzake. Bietan absolutibo argumentuak leku-aldaketa bat jasaten du, ohea helburu duena. (14b) adibidean, leku-aldaketa hori ergatiboz markatutako argumentuak eragin $\mathrm{du}$, arazleak alegia.

\section{EUSKARA UNIBERTSO TIPOLOGIKOAN: ADITZ LAGUNTZAILEAREN TXANDAKATZEA}

Aztergai dugun inkoatibo/arazle alternantzia (1), ez da, jakina, euskaraz bakarrik agertzen, eta gramatika sortzaileko lanetatik aparte, arreta handia eskaini zaio baita hizkuntza tipologiako lanetan ere. Gure lanak ez du helburu tipologikorik eta hortaz, ez du eremu honetan sakonduko, baina komeni da, euskarak, alternantzia honi dagokionez, gainerako hizkuntzen artean zein leku betetzen duen zehaztea. Horretarako, Haspelmath-i (1993) jarraituko diogu hurrengo lerrootan.

Inkoatibo/arazle alternantzia hiru motatako egituren bitartez azaltzen da Haspelmath-en arabera (2003, 90-92. orr.). Lehenik, arazle alternantzian, aldaera inkoatiboa da oinarrizko forma (eta hortaz, forma sinplea) eta aldaera arazlea morfologikoki konplexuagoa da. Izatez, aldaera inkoatiboan zein arazlean, aditzek itxura bera dute, baina arazlea konplexuagoa da inkoatiboa baino. Haspelmath-en esanetan, konplexutasun hori ager daiteke hizki baten bitartez (15a), aditz arazle batez (15b) edo erroaren aldaketaz (15c).

\begin{tabular}{|c|c|c|c|}
\hline a. & Georgiera & $\begin{array}{l}\text { duy-s } \\
a-d u y-e b s\end{array}$ & $\begin{array}{l}\text { 'sukaldatu (iragg.)' } \\
\text { 'sukaldatu (iragk.)' }\end{array}$ \\
\hline b. & Frantsesa & $\begin{array}{l}\text { fondre } \\
\text { fair fondre }\end{array}$ & $\begin{array}{l}\text { 'desegin (iragg.)' } \\
\text { 'sukaldatu (iragk.)' }\end{array}$ \\
\hline C. & Arabiera & $\begin{array}{l}\text { darasa } \\
\text { darrasa }\end{array}$ & $\begin{array}{l}\text { 'ikasi' } \\
\text { 'irakatsi' }\end{array}$ \\
\hline
\end{tabular}

(Haspelmath, 2003, 91. orr.)

Bigarrenik, antikausatiboan, aldaera arazlea da oinarrizkoa eta inkoatiboa morfologikoki konplexuagoa da, adibidez, gaztelaniazko romper aditzaren aldaera antikausatiboa romperse da. Antikausatiboa konplexuagoa da, beraz, eta hizki batez (gaztelaniazko se) edo antikausatiboa adierazten duen aditz batez zehazten da. Hirugarren eta azkenik, alternantzia norabidegabeak (ing. non-directed alternations) bereizten ditu Haspelmath-ek, eta euren artean, ekipolenteak, supletiboak eta ambitrantsitiboak (edo labile) bereizten ditu. Anbitrantsitiboetan (16a), erro bera erabiltzen 
da aldaera inkoatibo zein arazlean; supletiboetan (16b), berriz, aditz erro batek bestea ordezkatzen du;

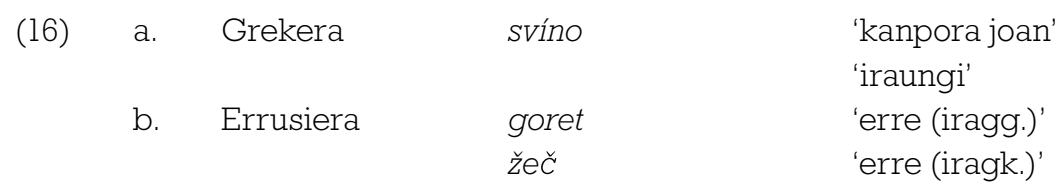

Ekipolenteetan azkenik, erro bera dugu, baina hizkiez (17a), aditz laguntzailea txandakatuz (17b) edo erroaren aldaketaz (17c) bereizten dira bi aldaerak.

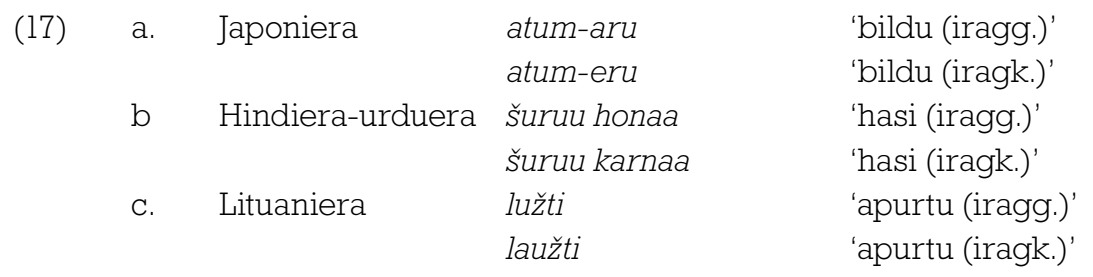

(Haspelmath, 2003, 91. orr.)

Kontuan izan Haspelmath estrategia morfologikoez ari dela oro har, hots, inkoatibo/arazle alternantzia hori nola adieraz daitekeen morfologikoki. Hortaz, ondoren euskararen inguruan esango dugunak zerikusia du inkoatibo/arazle alternantzia adierazteko estrategiekin, ez, jakina, inkoatiboaren edo arazlearen beraren existitzearekin.

Zehaztapen honen ostean, ikus dezagun, bada, unibertso tipologiko honetan, euskara non koka ote daitekeen. Hasteko, euskaraz ez dago halako arazle alternantziarik inkoatibo/arazleei dagokienez. Inori ikasi v irakatsi bezalakoak gogora baletozkio, kontuan hartu beharko luke -ra hizkia jasotzen duten arazleak ez direla gaur egun benetako arazleak, ezaguna denez irakatsi ez delako ikasiren arazlea ezta erakutsi ikusirena ere (ikasiren gaur egungo arazlea ikasarazi da eta ikusirena, berriz, ikusarazi). Euskaraz, morfema arazlea ez da dagoeneko produktiboa, arabieraz ez bezala (15c). Bestalde, hemen aztergai ditugun alternantzietan, hots, egoera-aldaketa, posizio-aldaketa eta leku-aldaketa adierazten duten horietan, ez dago halako -ra hizkidun aldaera arazlerik. Hortaz, ezin daiteke esan arazle alternantzia morfologikoa dagoenik, ez Haspelmath-en oinarrizko tipologian ezta Nicholson et alii-ren (2004) tipologia zehatzagoan ere.

Bestalde, euskaraz ez dago ezta alternantzia antikausatiborik ere, hots, ez dago antikausatiboa markatzeko estrategia morfologikorik (gogoratu, lehen esan dugun bezala, antikausatiboak aldaera inkoatiboa markatzen duela). Beste hizkuntza batzuetan, hala nola, islandieraz, antikausatiboa adierazteko estrategien artean dago aldaera inkoatiboa morfema antikausatiboaz adieraztea (Sigurdsson, 2012; Wood, 2015). Euskaraz, ez dago halakorik eta, guk dakigula behintzat, ezta egon ere. 
Alternantzia hau adierazteko, arazle morfologikorik ez badago ezta antikausatiborik ere, Haspelmath-en eta Nichols et alii-ren (2004) tipologietako alternantzia norabidegabeak baino ez zaizkigu gelditzen, eta itxuraz, alternantzia ekipolentea litzateke euskaraz jasotzen dena, hindiera/urdueraz dagoen bera alegia (Haspelmath, $2003)^{4}$, euskaraz ikusi dugunez, erro bera ( $h i l$ ) darabilgulako inkoatibo zein arazlerako, eta aditz laguntzailearen txandakatzeak (izan $\mathrm{v}$ "edun) dakarrelako bien arteko bereizketa ( $h i l d a \mathrm{v}$ hil $d u$ ). Aditz laguntzailearen txandakatzeari dagokionez, Nichols et alii-k (2004, 152. orr.) euskara bera ez ezik, Kaukasoko zenbait hizkuntza eta Ipar Australiako hizkuntzak aipatzen dituzte. Adibidez, Kaukasoko ipar-ekialdeko ingusheraz, ieghaz-d.uoda 'haserretu' (lit. haserre-joan) v ieghaz-d.ug 'haserrarazi' (lit. haserre-eraman) jasotzen da, hots, inkoatibo/arazle alternantziarako euskaraz bezala, aditz laguntzailea txandakatzen da. Nichols et alii-k (2004, 190. orr.) euskarari egozten dizkioten ezaugarri zehatzak gainerako hizkuntzetakoekin konpara daitezke.

Jakina, aditz laguntzailearen txandakatzearekin batera, badira sintaktikoki esanguratsuak diren beste alderdi batzuk, hala nola, argumentu bat (aldaera inkoatiboa) edo bi (aldaera arazlea) izatea; argumentu bakarrari absolutibo kasua ezartzea (aldaera inkoatiboan) eta arazlea den argumentuari eta gaiari, absolutibo eta ergatibo kasuak, ezartzea, hurrenez hurren, dagokien komunztadurarekin batera (aldaera arazlean). Alabaina, hauek ez dira euskarari soilik dagozkion alderdiak, izatez, aldaera inkoatiboan oro har, argumentu bakarra espero dugulako, iragangaitza den aldetik, eta arazlean, berriz, argumentu bi, iragankorra (edo iragankortua) delako. Aditz laguntzailea txandakatzea tipologikoki esanguratsua da, baina ez ordea, inkoatiboa argumentu bakarrekoa izatea edo arazlea argumentu bikoa, hori delako, oro har, batetik zein bestetik espero duguna.

Hurbilketa tipologikoa alde batera, gure azterbidean, inkoatibo/arazle alternantzia Boz alternantzia ere bada, ondoren ikusiko dugunez, eta Boz alternantzia hori dago zeinahi delarik inkoatibo/arazlea adierazteko estrategia morfologikoa. Euskaraz, hindiera/urdueraz edo ingusheraz bezala, aditz laguntzailea txandakatuz azaltzen da alternantzia, baina mekanismo sintaktiko bera da euskaraz zein bestelako estrategia morfologikoak darabiltzaten hizkuntzetan osatzen dena. Horixe da, behintzat, gure hipotesia. Hurrengo atalean emango diogu erantzun formala euskarak alternantzia honetan erakusten duen hautu tipologikoari eta munduko hizkuntzetan oro har inkoatibo/arazle alternantziari dagokionez azaltzen den mekanismo unibertsalari. 


\section{INKOATIBO/ARAZLE ALTERNANTZIA: AZTERBIDE BAT}

\subsection{Inkoatibo/arazle alternantzia, Boz alternantzia gisa}

Euskaraz inkoatibo/arazle alternantziari orain arte eskaini zaion analisirik osoena Oihartzabalek (2003) eman digu, eta analisi horren oinarriak gure lan honetara ere ekarriko ditugu. Ormazabalen (2008) analisiak ere bere aldetik badu oihartzunik gurean. Nolanahi ere den, guk lan honetan, beste bide berri bat urratu nahi genuke, aspaldion gaiaren inguruan argitaratu diren zenbait lanetatik abiatuz. Lan hauen oinarrian dagoen teoriaren arabera, inkoatibo/arazle alternantzia Boz alternantzia da (Alexiadou, 2010, 2014; Alexiadou et al., 2006, 2015; Wood, 2012, 2015, 2016 beste batzuen artean): Boza islatzen baldin bada eta argumentu bat baldin badu bere espezifikatzaile gunean, aldaera arazlea izango da; oso bestela, Boza islatzen ez bada, edota espezifikatzaile tematikorik ez badu, aldaera inkoatiboa izango da. Alde horretatik, Bozaren eta balizko argumentu tematiko baten islapenek baldintzatuko dute aditzak adierazten duen gertaeraren interpretazioa eta kanpo argumentuak jasotzen duen interpretazio bera ere. Euskaraz ere halaxe dela proposatuko dugu lan honetan. Gainerakoan, beste lan batzuetan, kanpo argumentuari dagokionez proposatu dena, guk ergatibo argumentuaren analisira ere ekarriko dugu Berrori (2015b) jarraituz. Ikusiko dugunez, gure proposamenean ez dago gertaera-egituran inolako desberdintasunik aldaera arazlearen eta inkoatiboaren artean (Ormazabal, 2008; cfr. Pylkkänen, 2002/2008; Oihartzabal, 2003).

Boza izaki kanpo argumentuaren islapena edo islapenik eza baldintzatuko duena, bi zaporetakoa (ing. flavor) delako ustea izango dugu Wood-ekin $(2014,2015,2016)$ bat etorriz.

(18) a. Bozak $\mathrm{LD}_{\{\mathrm{D}\}}$ erkatu behar duen D-tasun bat du -sarritan, D kategoriako zerbaitekin batuz Espez,BozS gunean-.

b. Bozak $_{\{\}}$ez du D-tasunik, eta ez du espezifikatzailearen beharrik.

(Wood, 2015)

Wood-en proposamena (eta ildo berekoak) ulertzeko berebiziko garrantzia dauka ulertzeak erroek ez dutela berez argumentu egiturarekin zerikusia duten egiturazko tasunik. Horregatik, edozein erro edozein egituratan aurki daiteke (Borer, 2005). Alabaina, erroa inguruko ezaugarri sintaktikoen arabera interpretatzen da (Wood, 2016: 2). Gainera, lan honetan Morfologia Banatuan egiten diren lanetan bezala (e. g. Marantz 1997, 2001, 2007), erroek kategoriarik ez dutelako ideiatik abiatuko gara eta, hortaz, apaiztu edo handitu bezalako aditzetan, a txikiaren osagarri gunean ez da izen edo adjektiborik islatuko, ezpada kategoriarik gabeko erro bat.

Hipotesi honi jarraituz, beraz, gure lanari hasiera eman dioten adibideen analisia ikus daiteke (19) eta (20)an, aldaera iragankor eta inkoatiborako, hurrenez hurren. 


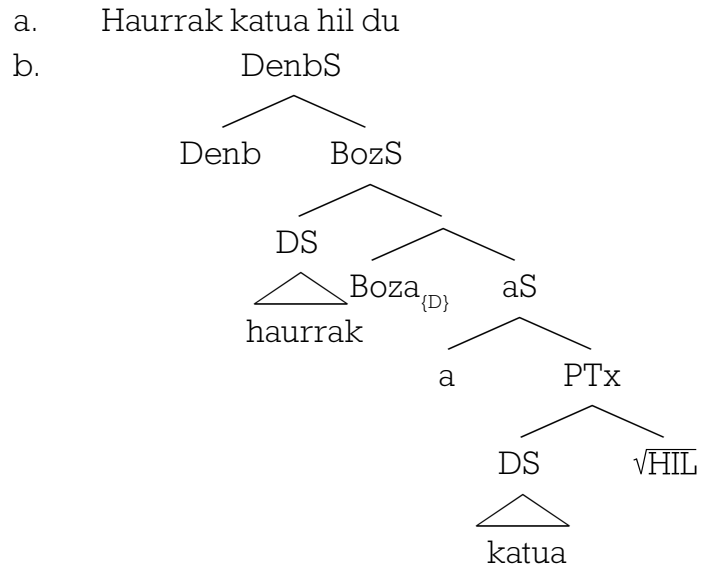

(20) a. Katua hil da

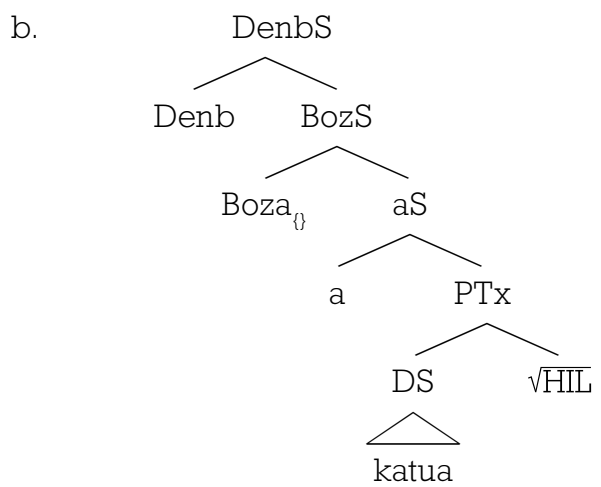

Ikusten denez, HIL erro bera agertzen da perpaus txikian eta Boz burua bi zuhaitzetan dago. Alabaina, aldaera arazlean (19), Bozak ${ }_{\{\mathrm{D}\}}$, haurrak kanpo argumentua gaineratzen du bere espezifikatzaile gunean, bere D-tasuna erkatuz horrela, eta aldaera

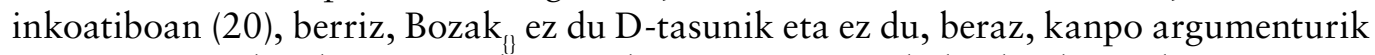
sartzen. Honi dagokionez, ez dago euskararen eta Wood-ek islandierarako proposatu duen analisiaren arteko alderik, nahiz eta hizkuntza bien artean alderik baden: euskaraz, islandieraz ez bezala, ez dago antikausatiborik, baina badago aditz laguntzailearen txandakatzea, zeina, goian ikusi dugunez, inkoatibo/arazlea adierazteko estrategia tipologikoen artean dagoen. Analisi sintaktikoak, hortaz, aditz laguntzailearen txandakatzea azaldu behar du hil da $\mathrm{v}$ hil $d u$ eratorriko baditu. Honi dagokionez, aditz laguntzailea eratorpenaren araberakoa dela proposatuko dugu lan honetan. Baldin eta

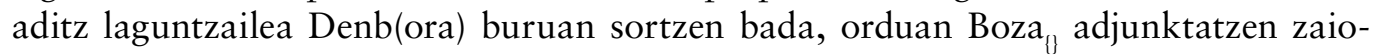
nean, izan gisa azalerazten da ( $h i l d a)$; aldiz, Denb buruari Boza ${ }_{\{D\}}$ adjunktatuz gero, - $u$ - erroaren bitartez azalerazten da $(h i l d u)$. ${ }^{*} E d u n$, beraz, aditz laguntzaile eratorria da hurbilketa honetan. 


\subsection{Inkoatibo/arazle alternantziarik gabeko errorik ba ote?}

Goian (2. atala) deskribatu ditugu euskaraz inkoatibo/arazle alternantzian parte har dezaketen erroak (i.e. egoera-, posizio- eta leku-aldaketa aditzetako erroak) eta erro horiek aditzaz gain, har dezaketen bestelako kategoria zein den kontuan hartuta sailkatu ditugu. Alabaina, mintzagai dugun gaiari dagokionez, berebiziko garrantzia duena da ea erro hauek guztiek inkoatibo/arazle alternantzian parte hartzen duten edo ez. Gure galderak hauexek dira beraz: ba ote da inkoatibo/arazle alternantziarik gabeko errorik? Ba al da aldaera inkoatiboa bai, baina arazlea ez duen errorik, edo alderantziz, arazlea duen errorik aldaera inkoatiboa izan gabe?

Jakina, goian deskribatu ditugun aditzek printzipioz aldaera bat zein bestea (eta hortaz, alternantzia) erakusten dute, baina batzuek badirudi bi aldaeretatik bat baino ez dutela (eta ondorioz, alternantziarik ez) -ikus baita Ormazabal (2008, 645. orr.)-. Adibidez, Egungo Euskararen Hiztegira (EEH), edo Elhuyarren hiztegira joaz, ureztatu aditzari dagokionez, batek zein besteak $d u$ dela adierazten dute ("edun aditz laguntzaile iragankorraren aipamena eginez), hots, aldaera arazlea baino ez dutela pentsarazten dute. Hala egiten dute baita garaztatu edo ibinztatu aditzekin ere. Nola erran hiztegiak (NE), bere aldetik, aditz iragankortzat jotzen du, baxenafar-lapurterazko tradizioko urtatu bezalaxe. Alternantziarik ez duen errotzat hartu beharko genuke, beraz, ureztatu (eta garaztatu eta ihinztatu), hiztegi horietara begira bederen. Alabaina, adibidez, Ereduzko Prosa Gaur (EPG) corpusera joaz -kontuan izan EEH corpus honetan oinarritzen dela-, badira tarteka, aldaera inkoatiboa (hots, $d a$ ) erakusten duten adibideak, hala nola, ondokoak:

(21) a. Lur arin eta gozoak erraz ureztatu daitezke ibaiko urekin (Lierni Arrieta, «Ebroren igurtziak», 2003/09/07, Argia, 1910)

b. Jabetzan hartzera zoazten lurraldea, berriz, bere mendi eta ibarrekin, zeruko euriz ureztatzen da (Askoren artean, Elizen arteko biblia, 2004, Dt 11,11)

Hau bezalako agerraldiak ez dira beharbada oso sarriak izango (ez dugu hemen maiztasun aldetiko azterketa egin ezta egin asmorik ere), baina kualitatiboki esanguratsuak dira bi alderditatik gutxienez: batetik, aldaera inkoatiboa erakusten dute, hots, hiztegiek jasotzen ez dutena, eta beste alde batetik, modifikatzaile bana erakusten dute, (21a) adibideak ibaiko urekin, komitatibo sintagma (-kin) eta (21b) adibideak, berriz, zeruko euriz, instrumentala $(-z)$. Luze joko luke eta azterketa beregaina mereziko luke komitatiboak eta instrumentalak kanpo argumentuarekin (viz. ergatiboarekin), eta kasu zehatz honetan, arazlearekin zein zerikusi duen eztabaidatzea, baina kontuan hartu beharra dago $(21 \mathrm{a}, \mathrm{b})$ adibideetako komitatiboa eta instrumentalak aldaera arazle bateko subjektu gisa ere eman litezkeela (22):

(22) a. Ibaiko urek lur arin eta gozoak erraz ureztatu ditzakete

b. Jabetzan hartzera zoazten lurraldea, berriz, zeruko urak ureztatzen du

4.4. atalean ikusiko dugunez, aldaera inkoatiboan $(21 \mathrm{a}, \mathrm{b})$, indar arazlea postposizio sintagmen bidez adierazi ahal izateak erakusten du aldaera inkoatiboak berak 
kausazko esanahia duela, eta hortaz, arazletasuna ez dela bakarrik aldaera arazleko ezaugarria.

EPGn badira, bestalde, egitura iragangaitzaren bestelako agerraldiak, hala nola:

Baratzeak eskuz ureztatuko dira, eta horretarako hainbat aska egongo dira baratze parte bakoitzean (Iñaki Lasa Etura, «Herritarrentzako baratze sarea», Berria, 2012/10/24)

Alabaina, hau bezalakoak ezin ditugu inkoatibotzat hartu, inpertsonaltzat baino ${ }^{5}$. Kontuan izan, adibidez, azken adibide honetako instrumentala erreminta gisa hartzen den gorputz atala dela (De Rijk, 2008, 742. orr.), eta (22)n ez bezala, ezin daitekeela arazlea izan:

\section{*Eskuek baratzeak ureztatuko dituzte}

Nolanahi ere den, eta gai nagusira itzuliz, ez da harritzekoa aldaera inkoatiboa agertzea komitatiboarekin edo instrumentalarekin. Gure ustez, testuinguru sintaktiko jakinek (hala nola, indar arazlea adierazten duen komitatiboaren eta instrumentalaren agerpenak) errazten dute aldaera inkoatiboaren agerpena. Oihartzabalek ere, alternantzia bete-betean erakusten duten beste erro batzuekin, hala nola, berdeturekin, (21,22) bezalakoak ere jasotzen ditu, goian (10) adibideetan erakutsi dugunez. Beraz, itxuraz alternantziarik ez duten erroek ere alternantzia erakuts dezakete testuinguru jakinetan (Rappaport Hovav, 2014; Alexiadou, 2010, 2014; Wood, 2016), eta erakutsi ezean, geroago ikusiko dugunez (4.3), erroek duten Forma Logikoko (FL) interpretazio-jarraibideei zor zaie (eta ez dena delako aditzaren berezko inongo ezaugarriri).

Kontrako norabidean ere gerta daiteke dena delako erroak alternantziarik ez erakustea, hots, aldaera inkoatiboa izatea, baina arazlea nekezago onartzea. Oihartzabalek (2003, 241, 18 oin-oharra) aipatzen dituenen artean dago loratu (edo loretu).

$$
\begin{aligned}
& \text { a. } \quad \% \text { Maiatzeko eguzkiak gereziondoak loratu ditu } \\
& \text { b. Gereziondoak loratu dira maiatzeko eguzkiarekin }{ }^{6}
\end{aligned}
$$

Loratuk barrutik arazitako gertakaria (ing. internally caused event) adierazten du (Levin \& Rappaport Hovav, 1995) eta beste hizkuntza batzuetan bezala, nekez

\footnotetext{
5 Badira inpertsonaltzat hartu ezin daitezkeen beste agerraldi iragangaitz batzuk, hala nola, ondoko zortziko txikian ageri dena: Ezin bizi gintezke / aterkirik gabe, / Gipuzkoan geratu da / busti bezain grabe / hola jarraitu ezkero / galduta bait gaude / ureztatuko gara / landareen pare (Miriam Juaristi, Berria, 2011 azaroak 16). Litekeena da egitura bihurkaria izatea hauxe.

6 Oihartzabalen (2003) adibidea da lehena eta gu hirurona bigarrena.
} 
onartzen dituzte kanpo arazleak ${ }^{7}$, izatez barruko arazleak dituzten erroek (Wood, 2016, 18. orr.). Ez da, hortaz, harrigarria aldaera arazlea onargaitza izatea hiztun batzuentzat. Horregatik, erro honi dagokionez, EEHk da dakar (aldaera inkoatiboaren berri emanez) eta NE hiztegiak ere aditz iragangaiztzat hartzen du loratu adiera honetan; $d u$ aldaerarako, hots, arazlerako loretan jarri, lorez bete adierak ematen ditu. Ereduzko Prosa Gaur (EPG) corpusetik jaso ditugu aldaera arazle hori erakusten duten zenbait adibide:

(26) a. Udaberriak baino goizago loratzen du zuhaitza xoriak bere kantuaz (Josanton Artze, M. Itzaina, «Jainkoa, bizia, jendea», Herria, 2001/08/09, 6. orr.)

b. Ez dezadan ahantz ere erraiteko Burgaintzi taldea, Amikuzetik komitatuta, bere kantu eta dantzez egun hori loratu duena. (Bego, «Pilota», Herria, 2004/09/30, 7. orr.)

c. Baratze zabalak eskaini aukeraz baliaturik, zizelatutako artelan garaikideek loratzen dutela gunea, soinu, kantu eta dantzen artean eguna pasatzea proposatzen dute (Nora Arbelbide, «Badüzia une poule para vender?», Berria, 2006/03/30)

Aldaera arazlea erakusten duten adibide hauetako loratu erroak esanahi idiosinkrasikoa du, metaforikoki eraikia baita esanahia, hots, ez da loratze hutsa hemen adierazten dena, batez ere $(26 \mathrm{~b}, \mathrm{c})$ adibideez ari garela, zeinetan Burgaintzi taldeak eguna lortu duen (b), eta artelan garaikideek gunea (c). Hauek eta antzeko adibideak, bai alternantziarik itxuraz ez dutenak bai esanahi idiosinkrasikoak erakusten dituztenak aztertu eta azalduko ditugu hurrengo atalean. Ikusiko dugunez, (26) bezalako agerraldiak erro-alosemiaren bidez azal daitezke.

\subsection{Erroen interfaze-jarraibideak}

Jo dezagun, beraz, badirela alternantzia erakusten ez duten erroak, eta erro berak askotariko interpretazioak izan ditzakeela. Halakoak erro-alosemiaren hautapenari egotzi izan zaizkio literaturan (ikus Arad, 2003, 2005, eta bere ildoko lanak, eta berriki Anagnostopoulou \& Samioti, 2014 eta Wood, 2016 beste batzuen artean).

7 Barrutik arazitako gertakariak adierazten dituzten aditzak alternantzia arazlean ere ager daitezke, berriki McKoon \& Macfarland-ek (2000), Wright-ek (2001, 2002) eta Alexiadou-k (2014) erakutsi duten bezala. Nolanahi ere, murriztapen gehiago dauzkate kanpo argumentuari dagokionez. Kanpotik arazitako gertakariak adierazten dituzten aditzetan, kanpo argumentua egilea izan daiteke arazle izateaz batera (i), baina barrutik arazitako aditzetan, kanpo argumentua egonez gero, arazle soila izan behar da, inolako egiletasunik gabea (ii).

(i) a. Atea zabaldu da

b. Jonek atea zabaldu du (Jon = egilea/arazlea)

(ii) a. Landarea loratu da

b. "Jonek landarea loratu du (Jon = egilea/arazlea)

c. \%Udaberriak landarea loratu du (Udaberria = egilea/arazlea)

Lan honetan ez dugu murriztapen honetaz jardungo. Besterik gabe, loratze esanahia mantentzen duen loraturen aldaera arazlea bazterrekotzat joko dugu. 
Atal honetan, lau kasu aztertuko ditugu eta proposamen bateratu bat egingo dugu. Lehenik eta behin, aldaera inkoatiboan bakarrik ager daitezkeen aditzak arakatuko ditugu (e. g. etorri, erori). Bigarrenik, kontrako kasuak aztertuko ditugu, hots, aldaera arazlea besterik ez duten aditzak (e.g. ekarri, atxilotu, legeztatu). Hirugarrenik, loratu aditza arakatuko dugu. 4.2 atalean ikusi dugunez, loratuk aldaera inkoatiboa bakarrik onartzen du oro har, baina egitura arazlean ere ager daiteke, baldin eta esanahi idiosinkrasikoa jasotzen badu. Laugarren eta azkenik, ureztatu aditzaren jokabidea aztertu eta azalduko dugu. Ureztatuk egitura arazlea izaten du gehienetan, baina inkoatiboa ere onar dezake, egoera-aldaketaren arazlea komitatibo edo instrumental sintagma baten bidez azaleratzen bada -ikus 4.2-.

Kasuon azterbidea, Harley (2014) eta Wood (2016) lanetan sustraitzen da. Morfologia Banatuan, erroak eduki fonologikorik eta semantikorik gabe sartzen dira sintaxian (e. g. Halle \& Marantz, 1993, 1994; Harley \& Noyer, 1999; Embick \& Noyer, 2007). Informazio hori sintaxiaren ondoren gaineratzen da. Horretarako, Harley-k (2014) eta Wood-ek (2016) proposatu dutenaren arabera, erro bakoitzak sintaxi ondorengo jarraibide zerrenda bat dauka, Forma Fonetiko (FF) eta FL interfazeetan harekin zer egin behar den zehazten dutenak. Erroen interfaze-jarraibideak dira. Jarraibide hauek finkatzen dute, besteak beste, erroek izango duten interpretazioa. Erro batek interpretazio bat baino gehiago izan ditzake egitura sintaktikoaren arabera, edo gerta liteke erro batek interpretaziorik ez edukitzea egitura sintaktiko jakin batean. Lan honetan, erroen ikuspegi hori abiapuntutzat hartuko dugu, eta berriki aipatutako kasuak azalduko ditugu banan-banan: aldaera inkoatiboa edota arazlea onartzen ez duten aditzak (e. g. erori, ekarri, legeztatu) aztertuko ditugu 4.3.1 atalean, eta 4.3.2 atalean, aldaera arazlea edota inkoatiboa esanahi jakin batekin edo testuinguru sintaktiko zehatz batekin bakarrik onartzen dituzten aditzak, i. e. loratu eta ureztatu, arakatuko ditugu.

\subsubsection{Aldaera inkoatiboa edota arazlea onartzen ez dutenak}

Goian (4.1) dagoeneko esan dugunez, Boza bi zaporetan ager daiteke sintaxian -(18) errepikatzen dugu hemen-:

(27) a. Bozak $k_{\{\mathrm{D}\}}$ erkatu behar duen D-tasun bat du-sarritan, D kategoriako zerbaitekin batuz Espez,BozS gunean-.

b. Bozak $_{\{\}}$ez du D-tasunik, eta ez du espezifikatzailearen beharrik.

(Wood, 2015).

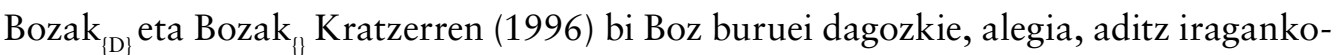
rretako Bozari eta aditz iragangaitzetako Bozari, hurrenez hurren. Euskaraz ere bi bertsio horiek daudela proposatuko dugu hemen. 4.1. atalean adierazi dugun bezala, al-

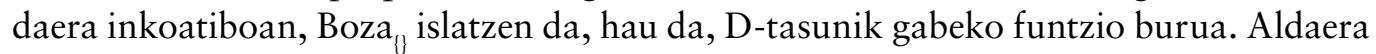
arazlean, ordea, Boza $_{\{\mathrm{D}\}}$ dago, eta horren ondorioz, Bozaren espezifikatzaile gunean D-tasuna duen argumentu bat islatu behar da.

Bestalde, esana dugu dagoeneko erro guztiek dituztela interfaze-jarraibideak. Horrek esan nahi du eratorpen sintaktikoan erroak ahoskatzera bidaltzen direnean, jarraibide 
horiek bete behar direla, bai FFn bai FLn. Esate baterako, Harley-ren (2014) arabera, ingelesezko throw 'bota' aditzak honako zehaztapenak dauzka (28).

a. $\quad \frac{\text { FFko jarraibideak }}{V_{77} \Leftrightarrow / \text { rrow/ }}$
b. $\quad$ FLko jarraibideak
$V_{77} \Leftrightarrow \ll$ botaka egin»/[a [-- $\left.][\mathrm{up}]_{\mathrm{P}}\right]_{\mathrm{aS}}$
$\Leftrightarrow$ «tapaki arina»/ [i [__r] ]
\{bestelako adierak beste testuinguru batzuetan...\}
$\Leftrightarrow \ll$ throw» / nonahi

Goian esan dugun bezala, erroak sintaxian sartzen direnean, ez dute eduki semantikorik ezta fonologikorik ere. Horregatik, indizeak erabiltzen ditugu erroak behar bezala bereizteko sintaxian $\left(V_{77}, \sqrt{25}_{25}, \sqrt{37}_{37}\right.$ etab.), hainbat lanetan egiten den bezala (Pfau, 2000, 2009; Acquaviva, 2008; Harley, 2014). FFn, $\sqrt{ }_{77}$ erroak / row/ ahoskera dauka. FLn, erroaren interpretazioa inguruko egitura sintaktikoaren araberakoa da. a txikiaren eta $u p$ partikularen testuinguruan, 'botaka egin' esanahia dauka. Bestalde, i(zena) ren eremuan, aldiz, 'tapaki zuria' adierazten du, eta azkenik, gainerako testuinguru guztietan, 'bota' esan nahi du.

Wood-ek (2016) islandierarako egin duen bezala, euskarazko arazle/inkoatibo alternantziako aldaera baten gabezia erroen interfaze-jarraibideen bidez azalduko dugu. Beraz, proposatuko dugu eror bezalako erro batek honako interfaze-jarraibideak dauzkala:

$$
\text { a. } \quad \frac{\text { FFko jarraibideak }}{\sqrt{25}_{25} \Leftrightarrow / \text { eror/ }}
$$
b. $\quad$ FLko jarraibideak
$V_{25} \Leftrightarrow$ «beherantz joan»/ [Boza $[$ [a [_- $\left.\left.\left.]\right]_{\text {aS }}\right]_{\text {BozS }}\right]$ $V_{25} \Leftrightarrow \ll$ goibeldu»/
$\left.\left[\text { Boza }_{\{\}}\left[\text {a bihotza/gogoa }\left[{ }_{--\checkmark}\right]\right]_{\text {aS }}\right]_{\text {BozS }}\right]$

Arazle/inkoatibo alternantzian agertzen diren aditz erroek bi egituretan interpretatu ahal izateko, bi testuinguruak egon behar dira zerrendatuta interfaze-jarraibideetan. Handi erroak, adibidez, horrelako interfaze-jarraibideak izango lituzte:

$$
\frac{\text { FFko jarraibideak }}{V_{37} \Leftrightarrow \text { /andi/ }}
$$

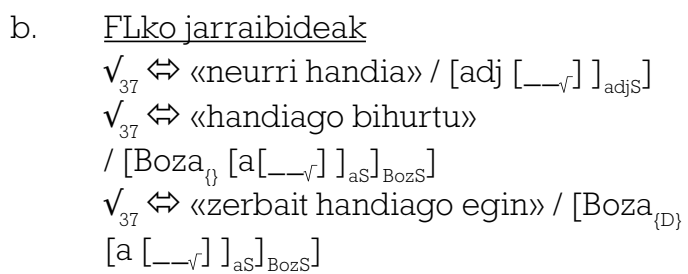

Handik ezaugarri bat adierazten du adj buruaren aldamenean; a txikiaren ondoan, aldiz, gertaera bat adierazten du, eta gertaera hori desberdina da Bozaren zaporearen arabera. Boza $\mathrm{B}_{\mid 1}$ ren ondoan, handik adierazten du «handiago bihurtu»; Boza ${ }_{\langle\mathrm{D}\rangle}$ ren ondoan, ordea, argumentu egile edo arazle batek eragindako gertaeratzat interpretatzen $\mathrm{da}$, hots, «zerbait handiago egin». Beraz, handi egitura inkoatiboan (hau da, Boza $\mathrm{u}_{11}$ ren testuinguruan) zein egitura arazlean (alegia, Boza $_{\{\mathrm{D}\}}$ ren testuinguruan) ager daiteke, bi egiturak interpreta daitezkeelako FLn. 

a. Zuloa handitu da
b. Jonek zuloa handitu du

Eror, aldiz, inkoatiboan bakarrik ager daiteke (32a), Boza ${ }_{\{\mathrm{D}\}}$ izango lukeen balizko egitura bat ezin litekeelako FLn interpretatu.
a. Giltzak erori dira
b. *Jonek giltzak erori ditu

Alderantzizko azalpena eman dakieke legeztatu eta atxilotu aditzei. Aditz horiek egitura arazlean baino ezin dira agertu. Gure analisian, atxilo erroak ondoko interfazejarraibideak izango lituzke:

$$
\text { a. } \quad \frac{\text { FFko jarraibideak }}{\sqrt{64}_{64} \Leftrightarrow / \text { atfilo/ }}
$$

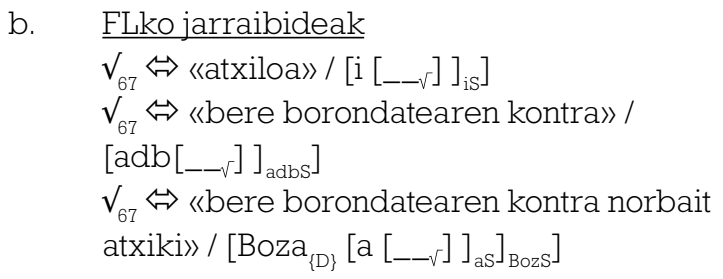

Atxilo erroa ezin ager daiteke aldaera inkoatiboan, egitura horretan Boza dagoelako eta horrelako egitura bat ezin interpreta litekeelako atxilok dituen interfaze-jarraibideekin.

$$
\text { a. *Jon atxilotu da }
$$$$
\text { b. Poliziak Jon atxilotu du }
$$

Horrenbestez, analisi honetan arazle/inkoatibo alternantziako aldaera baten gabezia, hala nola, (33b) eta (34a), erro bakoitzak dituen FLko jarraibideen zerrendari zor zaio. Boza $_{\{\}}$edo Boza ${ }_{\{\mathrm{D}\}}$ dituen egiturak FL interpretazio banarekin loturik agertzen ez badira, ezin izango dira interpretatu, eta ondorioz, eratorpenak huts egingo du.

\subsubsection{Esanahi idiosinkrasikoko aldaerak eta erro-alosemia}

4.2 atalean ikusi dugunez, loratu ezin ager daiteke egitura arazlean, ez bada esanahi metaforiko batekin, alegia, «zerbait agerrarazi» edo «zabaldu». Hona hemen, gorago eman ditugun (26) adibideez gain, EPGko beste adibide batzuk:

(35) a. [...] ardoaren inguruko berotasun sutsuak loratuko zituzten bertsoak [...] (Pako Aristi, Gauza txikien liburua, 2004, 143. orr.)

b. Irriñoak loratu zion berriz aho ingurua [...] (Aingeru Epaltza, Rock'n'roll, 2000, 233. orr.)

Adiera metaforikoa aldaera inkoatiboan ere ager daiteke.

(36) a. Historia hila erromantze hilezkorrean loratzen da (Iñaki Mendiguren, Historiaren azterketa II, A. J. Toynbee, 163. orr.) 
b. Bazkari eta beste ezinbesteko osagaiez loratuko da besta (Herria, 2005/02/27)

c. Sekula izan ez zituen begizulo batzuk loratu zitzaizkiola zirudien (Harkaitz Cano, Pasaia blues, 190. orr.) ${ }^{8}$

Wood-en (2016) ildoari jarraituz, agerpen horiek erro-alosemiari zor zaizkiola uste dugu, hots, FLko jarraibideetan zerrendatutako esanahiei. Lora (/lora/) ahoskatzen den erroak bi esanahi izan ditzake: bat literala eta bestea metaforikoa. Alabaina, bi adieren banaketa ez da bera. Hauexek izango lirateke lora erroaren interfaze-jarraibideak.

$$
\begin{aligned}
& \text { a. FFrako jarraibideak b. FLrako jarraibideak } \\
& V_{79} \Leftrightarrow \text { lora/ } \quad V_{79} \Leftrightarrow \text { «[adiera literala edo metaforikoa]» } \\
& \left./\left[\text { Boza }_{\{\}}\left[\mathrm{a}\left[{ }_{--}\right]\right]_{\mathrm{aS}}\right]_{\mathrm{BozS}}\right] \\
& V_{79} \Leftrightarrow \ll[\text { adiera metaforikoa bakarrik]» } \\
& \left./\left[\mathrm{Boza}_{\{\mathrm{D}\}}[\mathrm{a}[--J]]_{\mathrm{aS}}\right]_{\mathrm{BozS}}\right]
\end{aligned}
$$

Boza $_{\{\mathrm{D}\}}$ duen egitura era bakarrean interpreta daiteke, hots, loraturen zentzu metaforikoarekin, «zerbait agerrarazi».

Atal honetan aztertuko dugun bigarren kasua ureztaturen aldaera inkoatiboari dagokio. 4.2 atalean ikusi dugunez, ureztatun aldaera arazlea da nagusi, baina inkoatiboa ere izan daiteke, baldin eta postposizio sintagma komitatibo edo instrumental bat ondoan badu -ikus (21) adibideak-. Erabilera horiek urezta erroaren FLko jarraibideetan zerrendaturik daudela proposatuko dugu hemen. Gure analisiaren arabera, hiztunak badaki ureztaturen aldaera inkoatiboa interpretatzen -aldaera arazleaz gain-, betiere indar arazlea adierazten duen sintagma komitatibo edo instrumental baten testuinguruan.

$$
\text { a. } \quad \frac{\text { FFrako jarraibideak }}{\sqrt[V]{144}_{1} \Leftrightarrow / \text { uresta/ }}
$$

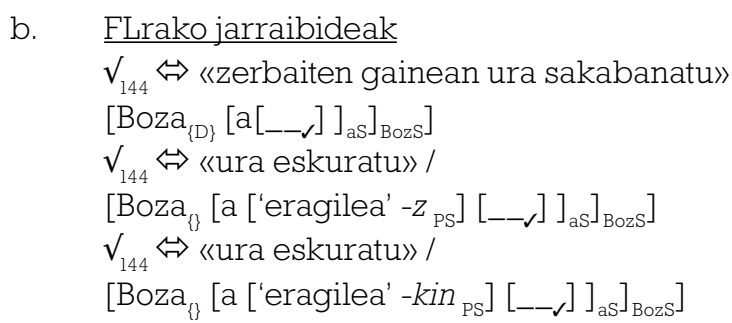

\subsection{Ergatiboaren interpretazioa}

Gatozen orain ergatibo argumentuen interpretazioa nola zehazten den aztertzera. Proposamen lexikalistetatik aldenduz eta oinarritzat hartu ditugun lanen espirituari jarraituz, gure proposamena da erroek ez dutela egiletasun esanahirik. Euskararen

$8 \mathrm{Ez}$ dugu hemen aurreratuko egitura datibodunen, hots, (35c) eta (36c) adibideen eratorpenik, baina ez dira printzipioz gure analisi teorikorako oztopo. 
kasurako esango dugu ergatibo argumentuaren arazle adiera egitura sintaktikotik eratortzen dela, eta hortaz, ergatiboa argumentuaren interpretazioa konfigurazioaren arabera zehazten dela (ikus horrelako analisi baterako, Berro, 2015b).

Aditzak zati txikiagotan bana daitezkeela aspaldiko ideia da (e. g. Lakoff, 1965; Dowty, 1979; Jackendoff, 1990 beste askoren artean). Esate baterako, hil arazlea (kill ingelesez) hil-arazi (cause to die) osagaietan bana daiteke, eta hil inkoatiboa (die) beste bi osagaitan, hots, hil bilakatu (become dead); azken egoera adierazten duen osagaia (bil-dead) eta gertaera bera (bilakatu-become). Osagai banaketa horretan oinarrituz, tradiziozko lan gehienetan (e.g. Dowty, 1979), aldaera arazleak eta aldaera inkoatiboak azpigertakari egitura desberdina dutela proposatu izan da:

(41) a. hil inkoatiboa: [BIHURTU [y < $<$ EGOERA $_{\text {hil }}>$ ]]

b. hil arazlea: [X ARAZI [BIHURTU [y < EGOERA $\left.\left.{ }_{\text {hil }}\right]\right]$

Gertakari egitura sintaxian islatzen dela (Hale eta Keyser, 1993 et seq.) asumituz, lan batzuetan, aldaera arazlean, inkoatiboan ez dagoen buru bat -arazle burua- islatzen dela proposatu izan da (hala nola Pylkkänen, 2008 [2002]; Cuervo, 2003 eta Oihartzabal, 2003 euskararako). Alabaina, 4.1 atalean esan dugun bezala, lan honetan ez dugu uste aldaera inkoatiboa eta arazlea gertaera egiturari dagokionez bereizten direnik (Ormazabal, 2008). 2 eta 4.2 ataletan ikusi dugunez, aldaera inkoatiboak, berdetu eta ureztaturenak adibidez, bateragarriak dira indar arazlea adierazten duten postposizio sintagmekin. Horrek erakusten du aldaera inkoatiboek ere arazitako egoerak adieraz ditzaketela, eta hortaz, arazletasunik ez zaiela falta. Alexiadou-k (2010), Alexiadou et alli-k $(2006,2015)$ horrelako grekerazko eta ingelesezko adibideak erabiltzen dituzte, besteak beste, aldaera inkoatiboak arazlearen gertaera-egitura bera duela esateko.

(42) a. The water on the surface gets warm from the sun.

b. My problem is that my den gets cold from the cold air in the garage.

(Alexiadou et al., 2015, 49. orr.)

(42a,b) adibideetan, from the sun 'eguzkiarekin' (lit. 'eguzkitik') eta from the cold air in the garage 'garajeko haize hotzarekin' (lit. 'haize hotzetik') preposizio sintagmek egoera aldaketen (i. e. get warm 'berotu' eta get cold 'hotzitu') indar arazleak adierazten dituzte. Hortaz, ezin esan daiteke aldaera inkoatibo horietan arazletasunik ez dagoenik. Aldaera arazleetan arazle buru bat dagoela proposatzen den lanetan, ezin da azaldu nola diren zilegi horrelako preposizio sintagmak, izan ere, aldaera inkoatiboan ez legoke arazle bururik eta ondorioz, ezingo litzateke sortu preposizio sintagma horiekin bateragarria den esanahi arazlerik.

Horregatik guztiagatik, Alexiadou et alli-ren (2005, 2015) lanetan esandakoa ontzat hartuko dugu: alternantzia honetako aldaera biak, alegia, aldaera inkoatiboa eta aldaera arazlea, berdinak dira gertaera egiturari dagokionez. Bietan dago a txiki bat eta bakarra (cfr. Ramchand, 2008), gertaera bat adierazten duena. Arazle/inkoatibo alternantzia, beraz, ez da gertakari egituraren alternantzia, baizik eta Boz alternantzia (Alexiadou, 2010; Alexiadou et al., 2015; Wood, 2015, 2016). Lanean zehar proposatu 
dugun bezala, aldaera arazlea sortzen da Bozak argumentu bat hartzen duenean bere espezifikatzaile gunean. Bozak ez duenean espezifikatzailerik, aldaera inkoatiboa sortzen da.

Arazle bururik ez badago gertakari egituran, sortzen den galdera bat da ea nola lortzen duen ergatibo argumentuak behar duen interpretazioa, hots, arazlearena. Atal honetan galdera hori erantzuten saiatuko gara. Wood-ek (2012) eta Berrok (2015b) egin bezala, kanpo argumentuaren interpretazioa Bozaren osagarriaren interpretazioarekin hertsiki lotuta dagoela proposatuko dugu: zehazki, ergatibo argumentuak arazle adiera lortzen du, baldin eta Bozaren osagarri gunean kausazko gertaera bat badago.

$$
\llbracket B o z a \rrbracket \leftrightarrow \lambda x_{e} \cdot \exists e_{s} \text {.kausazko gertaera(e).arazlea(X, e) }
$$

Bozak ez ditu, izatez, arazle argumentuak sartzen. Besterik gabe, osagarri gunean duen gertaerarekin gertaera-identifikazioa egiten du eta argumentu bat gaineratzen du gertaera horri loturik. Halaber, kasu jakin batean, hots, osagarri duen gertaera kausazkoa denean, Bozaren espezifikatzaileak arazle rola izango du, (43)n ikus daitekeen moduan.

Alabaina, gure analisiaren arabera, sintaxian ez da arazle bururik islatzen, eta hortaz, kausazko interpretazioa beste nolabait azaldu beharra dago. Alexiadou et alii-ren (2005, 2015) ildotik (ikus baita ere Ramchand, 2008 eta Berro, 2015b antzeko ideietarako), proposatuko dugu arazletasuna a txikia osagai egoeradun batekin bat egiten duenean sortzen dela.

$$
\text { Baldin eta } \exists e, \exists s[\text { gertaera }(e) \wedge \text { egoera }(s) \wedge e \rightarrow s] \text {, orduan kausazko gertaera (e) }
$$

(44)k honako esanahi hau dauka hitzez: baldin eta gertaera bat badago eta egoera bat badago, eta gertaerak egoera eragiten badu, orduan gertaera kausazko gertaeratzat interpretatuko $\mathrm{da}^{9}$. Ergatibo argumentuari dagokionez, kausazko gertaera bat baldin badago, gainean gaineratzen den Bozaren espezifikatzaileak -alegia, ergatibo argumentuak- arazle rola hartuko du.

Horrenbestez, proposamen honekin arazle rola edo kausazko interpretazioa ez da oinarritzen sintaxi buru jakin batzuetan, sintaxi konfigurazio osoan baino.

\section{ONDORIOAK}

Lan honetan euskararen inkoatibo/arazle alternantzia aztertu dugu. Erakutsi dugunez, alternantzia horretan parte hartzen duten aditzen artean daude egoera-, posizioeta leku-aldaketa adierazten dutenak. Euskaraz, beste hizkuntza batzuetan ez bezala, ez

9 Osagai egoeraduna dagoen ala ez erroak berak baldintzatzen du. Harley-ren (2005) arabera, erroak gertaerak edota egoerak izenda ditzakete. Kausazko gertaeren kasuan, erroek egoerak izendatzen dituzte. 
dago ez aldaera arazlea adierazteko morfema arazlerik ezta aldaera inkoatiboa markatzeko antikausatiborik. Oso bestela, euskaraz, aditz laguntzailearen txandakatzean (izan $\mathrm{v}$ *edun) datza alternantzia, adibidez inghusera kaukasiar hizkuntzan bezala.

Lanean proposatu dugu inkoatibo/arazle alternantzia hori Boz alternantzia dela azken batean: aldaera inkoatiboan Boza ${ }_{n}$, hots, D-tasunik gabeko funtzio burua islatzen dela aldarrikatu dugu; aldaera arazlean, berriz, Boza ${ }_{\{\mathrm{D}\}}$, Bozaren espezifikatzaile gunean D-tasuna duen argumentu bat gaineratzera dakarrena. Bestalde, aldaeretako baten gabezia, FLko interfaze-jarraibideei egotzi diegu, Wood-ek (2016) islandierarako bezala. Azkenik, erro baten ezohiko aldaera, hala nola, loraturen aldaera arazlea, esanahi metaforikoarekin lotu dugu edo ureztaturen aldaera inkoatiboa testuinguru jakin batekin, eta bata zein bestea erro-alosemiaren bitartez azaldu dugu.

Hemen plazaratzen dugun hipotesi sortak izango du zer hobetua gerora begira, baina erroen teoriak azalduko ditu agian, orain artean ez gramatika teoria orokorrak ez euskal gramatikak azaldu ez dituen zirrikituak. Izan bedi hau bide horretan urrats berri bat horren maitea dugun bide urratzaileari segika.

\section{ERREFERENTZIAK}

Acquaviva, P. (2008). Roots and lexicality in Distributed Morphology. Eskuizkribua. Dubling University College.

Alexiadou, A. (2010). On the morpho-syntax of anticausative verbs. In M. R. Hovav, E. Doron \& I. Sichel (arg.), Syntax, lexical semantics and event structure (177-203. orr.). Oxford: Oxford University Press.

Alexiadou, A. (2014). The problem with internally caused change-of-state verbs. Linguistics, 52(4), 879-910.

Alexiadou, A., Anagnostopoulou, E. \& Schäfer, F. (2006). The properties of anticausatives crosslinguistically. In M. Frascarelli (arg.), Phases of Interpretation, (187-211. orr.). Berlin: Mouton.

Alexiadou, A., Anagnostopoulou, E. \& Schäfer F. (2015). External arguments in transitive alternations: A layering approach. Oxford: Oxford University Press.

Anagnostopoulou, E. \& Samioti, Y. (2014). Domains within words and their meanings: a case study. In A. Alexiadou, H. Borer \& F. Schäfer (arg.), The syntax of Roots and the roots of Syntax (81-111. orr.). Oxford: OUP.

Arad, M. (2003). Locality constraints on the interpretation of roots: The case of Hebrew denominal verbs. Natural Language and Linguistic Theory, 21, 737-778.

Arad, M. (2005). Roots and patterns: Hebrew morpho-syntax. Dordrecht: Springer.

Berro, A. (2015a). From adpositions to events. The case of location verbs in Basque. In L. Nash \& P. Samvelian (arg.), Approaches to complex predicates (20-45. orr.). Leiden/Boston: Brill.

Berro, A. (2015b). Breaking verbs. From event structure to syntactic categories in Basque (doktore tesia). UPV/EHU eta UBM.

Comrie, B. (1989). Language Universals and Linguistic Typology. Chicago: Chicago University Press. 
Cuervo, M. C. (2003). Datives at large (doktore tesia). NYU.

De Rijk, R. P. G. (2008). Use of the instrumental case. In R. P. G. de Rijk, Standard Basque: a progressive Grammar (737-780. orr.). Cambridge, MA: MIT Press.

Deustuko Hizkuntzalaritza Mintegia. (1989). Inkorporazioa perpaus kausatiboetan. In P. Salaburu (ed.), Sintaxi Teoria eta euskara (87-108. orr.). Donostia: UPV/EHU.

Dowty, D. R. (1979). Word meaning and Montague Grammar. The semantics of verbs in times in Generative Semantics and in Montague's PTQ. Dordrecht: D. Reidel Publishing Company.

Elhuyar Fundazioa.(d. g.). Elhuyar euskara-gaztelania/castellano-vasco Hiztegia. Hemendik hartua: https://hiztegiak.elhuyar.eus/eu_es/

Embick, D. \& Noyer, R. (2007). Distributed Morphology and the Syntax/Morphology interface. In G. Ramchand \& C. Reiss (ed.), The Oxford Handbook of Linguistic Interfaces (289-324. orr.). Oxford: OUP.

Etxepare, R. (2003). Valency and argument structure in the Basque verb. In J. I. Hualde \& J. Ortiz de Urbina (ed.), A Grammar of Basque (363-426. orr.). Berlin / New York: Mouton de Gruyter.

Halle, M. \& Marantz, A. (1993). Distributed Morphology and the Pieces of Inflection. K. Hale \& S. J. Keyser (arg.), The View From Building 20 (111-176. orr.). Cambridge: The MIT Press.

Halle, M. \& Marantz, A. (1994). Some Key Features of Distributed Morphology. A. Carnie \& H. Harley (arg.), Papers on phonology and morphology, MITWPL, 21, 275-288.

Harley, H. (2005). One-replacement, unaccusativity, acategorial roots, and Bare Phrase Structure. S. Gorbachov \& A. Nevins (arg.), Harvard Working Papers on Linguistics, 11, 59-78.

Harley, H. (2014). On the identity of roots. Theoretical Linguistics, 40(3), 225-276.

Harley, H. \& Noyer, R. (1999). State-of-the-art-article: Distributed Morphology. GLOT International, 4(4), 3-9.

Haspelmath, M. (1993). More on the typology of inchoative/causative verb alternations. In B. Comrie \& M. Polinsky (arg.), Causatives and Transitivity (87-120. orr.). Amsterdam: John Benjamins.

Jackendoff, R. (1990). Semantic Structures. Cambridge, MA: The MIT Press.

Kratzer, A. (1994). The event argument and the semantics of voice. Eskuizkribua. Univ. of Massachusetts.

Kratzer, A. (1996). Severing the external argument from its verb. In J. Rooryck \& L. Zaring (arg.), Phrase structure and the lexicon (109-137. orr.). Dordrecht: Kluwer.

Lakoff, G. (1965). On the nature of syntactic irregularity (doktore tesia). Indiana University.

Levin, B. (1993). English verb classes and alternations: A preliminary investigation. Chicago: The University of Chicago Press.

Levin, B. \& Rappaport Hovav, M. (1995). Unaccusativity: At the syntax-lexical semantics interface. Cambridge, MA: The MIT Press.

Marantz, A. (1997). No Escape from Syntax: Don't Try Morphological Analysis in the Privacy of Your Own Lexicon. University of Pennsylvania Working Papers in Linguistics, vol. 4-2.

Marantz, A. (2001). Words (handout). WCCFL, 20, USC, 2001eko otsaila. 
Marantz, A. (2007). Phases and Words. In S. H. Choe (ed.), Phases in the Theory of Grammar (191-222. orr.). Seoul: Dong In.

Mckoon, G. \& Macfarland, T. (2000). Externally and internally caused change of state verbs. Language, 76, 833-858.

Nichols, J., Peterson, D. A. \& J. Barnes (2004). Transitivizing and detransitivizing languages. Linguistic Typology, 8, 149-211.

Oihartzabal, B. (2003). Lexical causatives and causative alternation in Basque. In Inquiries into the Lexicon-syntax Relations in basque (223-253. orr.). Bilbo: UPV/EHU. (ASJUren Gehigarriak, 46).

Oihartzabal, B. et al. (2009-2013). Nola erran. Frantses-euskara hiztegi elektronikoa. Hemendik hartua: http://www.nolaerran.org

Ormazabal, J. (2008). Kausatibo aldizkatzeak euskaraz eta inguruko hizkuntzetan. In X. Artiagotia \& J. Lakarra (ed.), Gramatika jaietan Patxi Goenagaren omenez (643-663. orr.). Bilbo: UPV/EHU. (ASJUren Gehigarriak, 51).

Ortiz de Urbina, J. (1989). Parameters in the Grammar of Basque. Dordrecht: Foris.

Ortiz de Urbina, J. (2003) Causatives. In J. I. Hualde \& J. Ortiz de Urbina (ed.), A Grammar of Basque (592-605. orr.). Berlin/New York: Mouton de Gruyter.

Ortiz de Urbina, J. (agertzear). Complex causative verbs and causees in Basque (and Romance). In A. Berro, B. Fernández \& J. Ortiz de Urbina (arg.), Basque and Romance: Aligning grammars. Leiden/Boston: Brill.

Pfau, R. (2000). Features and categories in language production (doktore tesia). Johann Wolfgang Goethe-Universität.

Pfau, R. (2009). Grammar as processor; a distributed morphology account of spontaneous speech errors. John Benjamins Publishing Company.

Pylkkänen, L. (2008 [2002]). Introducing Arguments. Cambridge: MIT Press.

Rappaport Hovav, M. (2014). Lexical content and context: The causative alternation in English revisited. Lingua, 141, 8-29.

Sarasola, I., 2008-, Egungo euskararen hiztegia, UPV/EHU, Euskara Institutua. Hemendik hartua: http://www.ehu.eus/eeh/

Sarasola, I., Salaburu, P. \& Landa, J. (2001-2007). Ereduzko prosa gaur (EPG), UPV/ EHU, Euskara Institutua. Hemendik hartua: http://www.ehu.eus/euskaraorria/euskara/ereduzkoa/

Schäfer, F. (2008). The syntax of (Anti-)causatives. Philadelphia: Jon Benjamins.

Wood, J. (2012). Icelandic morphosyntax and argument structure (doktore tesia). NYU.

Wood, J. (2014). Reflexive -st verbs in Icelandic. Natural Language and Linguistic Theory, 32(4), 1387-1425.

Wood, J. (2015). Icelandic morphosyntax and argument structure. Dordrecht: Springer.

Wood, J. (2016). How roots do and don't constrain the interpretation of Voice. Working Papers in Scandinavian Syntax, 96, 1-25.

Wood, J. \& Marantz, A. (2017). The interpretation of external arguments. In R. D’Alessandro, I. Franco \& Á. J. Gallego (eds.), The verbal domain (255278. orr.). Oxford: OuP.

Wright, S. (2001). Internally caused and externally caused change of state verbs. Evanston, IL: Northwestern University dissertation.

Wright, S. (2002). Transitivity and change of state verbs. BLS, 28, 339-350. 